\title{
Performance and hematology of pacu fed diets supplemented with vitamins $\mathrm{C}$ and/or $\mathrm{E}$
}

\author{
Fabiana Garcia ${ }^{1 *}$; Fabiana Pilarski²; Eduardo Makoto Onaka ${ }^{1}$; Flávio Ruas de Moraes ${ }^{2,3}$ \\ ${ }^{1}$ APTA Polo Noroeste Paulista, C.P. 61 - $15500-000$ - Votuporanga, SP - Brasil. \\ ${ }^{2}$ UNESP/CAUNESP, Via Prof. Paulo Donato Castellane, s/n - 14884-900 - Jaboticabal, SP - Brasil. \\ ${ }^{3}$ UNESP/FCAV - Depto. de Patologia Veterinária - Via Prof. Paulo Donato Castellane, s/n - 14884-900 - \\ Jaboticabal, SP - Brasil. \\ *Corresponding author <fgarcia@apta.sp.gov.br>
}

\begin{abstract}
Pacu (Piaractus mesopotamicus Holmberg, 1887) is a valued Brazilian fish species for aquaculture. This is highly susceptible to disease, and feed supplementations for pacu can be a very important strategy to prevent disease incidence in fish farms. The aim of this study was to evaluate a strategic supplementation for pacu. Juvenile pacu $(10.5 \pm 1.2 \mathrm{~g})$ were fed diets containing three levels of vitamins $C$ and/or $\mathrm{E}\left(0,250\right.$, and $500 \mathrm{mg}$ vitamin $\mathrm{kg}^{-1}$ diet). Fish were fed diets without supplementation for two months prior to the experiment. After that period, experimental feeding was initiated for two months. Growth and hematological evaluations were made on the thirtieth and sixtieth days of feeding. Pacu fed diet without supplementation of vitamins C and E during 120 days did not show clear typical signs of deficiency. Fish fed diet vitamins $C$ and $E$ free increased feed intake, but no improvement on growth performance was detected. Vitamin E proved essential for erythrocyte protection, so that the higher the level of this vitamin in diet, the smaller the number of erythroblasts. Supplementation with $500 \mathrm{mg}$ of vitamin $\mathrm{C}$ and $250 \mathrm{mg}$ of vitamin $\mathrm{E}$ for 60 days increased the production of monocytes, thrombocytes and special granulocytic cells in pacu.
\end{abstract}

Key words: Piaractus mesopotamicus, ascorbic acid, feed supplementation, tocopherol

\section{Desempenho e hematologia do pacu alimentado com dietas suplementadas com vitaminas $\mathrm{C}$ e/ou $\mathrm{E}$}

\begin{abstract}
RESUMO: O pacu (Piaractus mesomotamicus Holmberg 1887) é uma espécie altamente valiosa para a aqüicultura brasileira. Entretanto, trata-se de uma das espécies mais susceptíveis a doenças. Por isso, a suplementação alimentar para o pacu pode representar importante estratégia de prevenção da incidência das enfermidades em pisciculturas. Pacus $(10,5 \pm 1,2 \mathrm{~g})$ foram alimentados com dietas contendo três níveis de vitamina C e/ou E (0, 250 e $500 \mathrm{mg}$ vitamina $\mathrm{kg}^{-1}$ de dieta). Os peixes foram alimentados com dieta não purificada sem suplementação durante os primeiros 60 dias para reduzir as reservas teciduais das vitaminas. Após este período, os peixes foram alimentados com as dietas testadas durante 60 dias. As avaliações de crescimento e hematologia foram realizadas no $30^{\circ}$ e $60^{\circ}$ dias. Pacus alimentados com dieta sem suplementação com as vitaminas C e E durante 120 dias não apresentaram sinais claros típicos de deficiência. Os peixes que receberam a dieta deficiente em vitamina $\mathrm{C}$ e $\mathrm{E}$ apresentaram maior consumo de ração, porém sem melhora no desempenho produtivo. A vitamina E mostrou-se essencial para a proteção dos eritrócitos, sendo que quanto maior o nível desta vitamina na dieta, menor o número de eritroblastos. A suplementação com $500 \mathrm{mg}$ de vitamina C e $250 \mathrm{mg}$ de vitamina E durante 60 dias aumentou a produção de monócitos, trombócitos e células granulocíticas especiais em pacu.

Palavras-chave: Piaractus mesopotamicus, ácido ascórbico, suplementação alimentar, tocoferol
\end{abstract}

\section{Introduction}

Pacu (Piaractus mesopotamicus Holmberg 1887) is highly valued Brazilian fish species for aquaculture due its acceptance by consumers and high growth rate. Its diet includes leaves, plant residues, fruit, which are rich in vitamins (Abimorad et al., 2009; Abimorad and Carneiro, 2007; Jomori et al., 2003). In fish farms, vitamins $C$ and $E$ should be antioxidant compounds of great value for this species, which is highly susceptible to diseases under stressful conditions (Martins et al., 2002).

Vitamin $\mathrm{C}$ contributes toward both bone and cartilaginous tissue formation and its deficiency in the diet causes bone and gill deformations, body and internal-organ hem- orrhages, lack of appetite and an increase in the negative consequences of stress (Mitoma and Smith, 1960). This vitamin in diets for aquatic organisms prevents the negative effects of stress and enhances their immune response (Petric et al., 2003; Sarma et al., 2009).

Vitamin E protects cell membranes against lipid peroxidation and its deficiency causes reduction on survival index, deformations in erythrocyte membranes, high in vitro hemolysis, loss of appetite, low feed conversion efficiency, muscular dystrophy and shortening of the opercula (Chien et al., 1999; Garcia et al., 2007; Hamre et al., 1997; Sau et al., 2004; Tocher et al., 2002).

Studies of hematological variables have become important as an auxiliary tool for the diagnosis and determination of fish health status (Tavares-Dias and Moraes, 2004). Con- 
sequently, cells should be identified and quantified to clarify the role of these vitamins in pacu defense mechanisms and to indicate the nutrient requirements for this species to improve its performance and health. The aim of this investigation was to evaluate growth performance and hematological parameters of pacu fed diets supplemented with different levels of vitamins $\mathrm{C}$ and/or $\mathrm{E}$ and study their interactions to recommend a strategic supplementation for farmers.

\section{Material and Methods}

The experiment was carried out in a randomized block design with three blocks (replications), in a $3 \times 3$ factorial combination. Each block constituted of different condition under which tanks were placed, inside or outside of the laboratory. Three vitamin $\mathrm{C}$ and three vitamin $\mathrm{E}$ levels in feed $\left(0,250\right.$, and $500 \mathrm{mg} \mathrm{kg}^{-1}$ of vitamin) were tested. Juvenile pacu $(10.5 \pm 1.2 \mathrm{~g})$ were distributed in tanks $(300 \mathrm{~L})$ with water renewal and continuous aeration at a stocking density

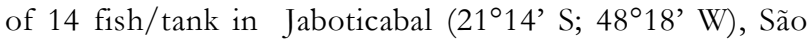
Paulo State, Brazil.

To decrease fish vitamin reserves, fish were stocked during two months in an environment with low incidence of light, preventing occurrence of phytoplankton, which is rich in vitamin $C$. The diet offered in this period was also vitamin $\mathrm{C}$ and $\mathrm{E}$ free. After that, fish were fed experimental diets at a rate equal to $5 \%$ of the weight of the fish in two feedings daily for two months.

The basal diet was formulated and prepared to reach the nutritional requirements of pacu (Table 1). A vitamin and mineral supplement used did not contain vitamins $C$ and E. The diet was prepared as follows: all ingredients were finely ground and weighed. The vitamin and mineral supplement, as well as the vitamin $\mathrm{C}$ and $\mathrm{E}$ sources at the desired levels, were incorporated into ground corn and the remaining ingredients. Feed was pelletized $\left(65^{\circ} \mathrm{C}\right)$ using a die which produced pellets with $2.5 \mathrm{~mm}$ in diameter and $7 \mathrm{~mm}$ in length.

Table 1 - Composition of basal and experimental diets, expected and detected vitamin $\mathrm{C}$ and vitamin $\mathrm{E}$ levels added to the experimental diets.

\begin{tabular}{|c|c|c|c|c|}
\hline \multirow{2}{*}{$\begin{array}{l}\text { Ingredient } \\
\text { Soybean bran }\end{array}$} & \multicolumn{2}{|r|}{$\%$} & & \\
\hline & \multicolumn{2}{|r|}{26.22} & & \\
\hline \multicolumn{2}{|l|}{ Corn } & \multicolumn{2}{|l|}{31.13} & \\
\hline \multicolumn{2}{|l|}{ Wheat bran } & \multicolumn{2}{|l|}{28.58} & \\
\hline \multicolumn{2}{|l|}{ Fish meal } & \multicolumn{2}{|l|}{11.62} & \\
\hline \multicolumn{2}{|l|}{ Soybean oil } & \multicolumn{2}{|l|}{1.95} & \\
\hline \multicolumn{2}{|l|}{ Vitamin and mineral supplement* } & 0.50 & & \\
\hline \multicolumn{3}{|l|}{ Calculated Composition } & & \\
\hline Crude Protein (\%) & & \multicolumn{2}{|l|}{26.00} & \\
\hline Ether Extract (\%) & & \multicolumn{2}{|l|}{7.00} & \\
\hline Crude Fiber (\%) & & \multicolumn{2}{|l|}{5.81} & \\
\hline Gross Energy ( $\mathrm{kcal} \mathrm{kg}^{-1}$ feed) & & \multicolumn{2}{|l|}{4,150} & \\
\hline Nitrogen-free Extract (\%) & & \multicolumn{2}{|l|}{44.00} & \\
\hline Mineral Matter & & \multicolumn{2}{|l|}{6.77} & \\
\hline \multirow{2}{*}{ Treatment } & Vitamin $\mathrm{C}$ & Vitamin E & Vitamin C & Vitamin E \\
\hline & \multicolumn{2}{|c|}{ Expected Level } & \multicolumn{2}{|c|}{ Detected Level } \\
\hline \multicolumn{5}{|c|}{ 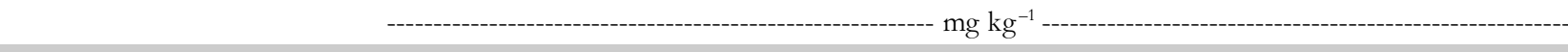 } \\
\hline 1 & 0 & 0 & trace** & trace \\
\hline 2 & 250 & 0 & 234 & trace \\
\hline 3 & 500 & 0 & 461 & trace \\
\hline 4 & 0 & 250 & trace & 223 \\
\hline 5 & 0 & 500 & trace & 460 \\
\hline 6 & 250 & 250 & 233 & 251 \\
\hline 7 & 250 & 500 & 240 & 482 \\
\hline 8 & 500 & 250 & 482 & 235 \\
\hline 9 & 500 & 500 & 484 & 519 \\
\hline
\end{tabular}

Sci. Agric. (Piracicaba, Braz.), v.68, n.3, p.314-319, May/June 2011 
Vitamin C and E sources used were ascorbyl polyphosphate $-35 \%$ activity and tocopherol adsorbate $50 \%$ activity, respectively. The vitamin concentration calculations for each treatment were made based on vitamin activity of the products. Feed was stored in plastic bags and frozen. Feed samples were analyzed to determine vitamins $\mathrm{C}$ and $\mathrm{E}$ levels in the diets (Table 1).

The following aquatic variables were monitored daily during the experimental period: temperature and dissolved oxygen, with an oximeter YSI model 55, pH, with a Corning meter and water conductivity, with a Corning conductivimeter. Water renewal rate was controlled once a week. Aquatic variables were maintained within recommended values for fish welfare: temperature $30.5 \pm 1.8^{\circ} \mathrm{C}$, dissolved oxygen $4.8 \pm 0.8 \mathrm{mg} \mathrm{L}^{-1}$, electric conductivity 204.1 $\pm 28.1 \mu \mathrm{S} \mathrm{cm}^{-1}$ and $\mathrm{pH} 8.6 \pm 1.1$. Water renewal rate maintained at $45 \pm 15 \mathrm{~mL} \mathrm{~s}^{-1}$.

Feed intake (FI) was determined once a week. Monthly, fish were measured and weighted to determinate weight gain (WG), feeding conversion (FC) and condition factor (CF), according the equations 1 to 3 :

WG $(\mathrm{g})=$ Final weight - Initial weight

$\mathrm{FC}=\mathrm{FI} / \mathrm{WG}$

$\mathrm{CF}=\left[\right.$ Weight $\left.(\text { Length })^{3}\right] \times 100$

Blood was collected and analyzed monthly during the two months of feeding with experimental diets. Blood aliquots $(1.0 \mathrm{~mL})$ were collected by puncturing the anal fins of two specimens per tank in each collection, using syringes containing EDTA (10\%). Erythrocyte counts were obtained with an automatic blood cell counter (Celm Model CC510) and the hemoglobin rate was obtained according to Collier's method (1944). Hematocrit was determined according to recommendations of Goldenfarb et al. (1971). Corpuscular constants such as mean corpuscular volume (MCV), mean corpuscular hemoglobin $(\mathrm{MCH})$, and mean corpuscular hemoglobin concentration (MCHC) were calculated according to Wintrobe (1934). Differential leukocyte counts were obtained by preparing panchromaticallystained smears. Cells were examined under light microscopy. Up to 200 cells per smear were counted, and percentages were established for each cell component of interest. Total leukocytes, total thrombocytes, and erythroblasts were indirectly quantified in the same smears by counting the numbers of thrombocytes, leukocytes, and erythroblasts for each 2,000 erythrocytes (Tavares-Dias and Moraes, 2004).

ANOVA assumptions were evaluated by the ShapiroWilk's tests for residue normality and Levene's test for homogeneity of variances. A $3 \times 3 \times 2$ factorial combination was used to analyze the influence of the main effects (three vitamin $\mathrm{C}$ levels, three vitamin $\mathrm{E}$ levels, and two evaluation times) and the interactions between them (vitamin $\mathrm{C} \times$ vitamin $\mathrm{E}$, vitamin $\mathrm{C} \times$ time, and vitamin $\mathrm{E} \times$ time), using two-way factorial ANOVA (Steel and Torrie, 1960). Means that showed differences between the factors were compared by Tukey's test $(p=0.05)$.

\section{Results and Discussion}

Levels of vitamins $\mathrm{C}$ and $\mathrm{E}$ detected in the diet were similar to the levels added (Table 1). No typical signs of deficiency were observed in fish during the studied period. Scurvy signs in rainbow trout (Onchorynchus mykiss), such as scoliosis, lordosis, dark skin color, pale gills, lethargy and swimming on the tank surface appear after 18 weeks of feeding vitamin C free (Navarre and Halver, 1989). Pintado (Pseudoplatystoma corruscans) fed a vitamin C-deficient diet for 12 weeks showed head convexity, fragile fins, and a posteriorly-displaced mandible (Fujimoto and Carneiro, 2001). It is possible that carnivorous species, such as trout and pintado, are more susceptible to this vitamin deficiency and must have higher requirements for these vitamins than omnivorous species (Abimorad and Carneiro, 2007; Fujimoto and Carneiro 2001; Mitoma and Smith, 1960).

Supplementation with vitamins $\mathrm{C}$ and $\mathrm{E}$ changes fish feed intake: the greater the vitamin deficiency the greater the feed intake (Table 2). This behavior has not been observed in other fish species (Bai and Lee, 1998; Fujimoto and Carneiro, 2001; Halver, 1953). However, for pacu it is suggested that the species tries to supply these vitamin deficiencies by an intake of a greater amount of feed. In a natural habitat, this species has a peculiar behavior of looking for better food, varying the sources as a function of season. Wild pacu ingests diversified foods, including leaves, plant residues, fruit and much less often, fish and/or mollusks or crustaceans (Abimorad and Carneiro, 2007). Anyway, the improvement on feed intake did not increase performance parameters because of the damage caused by deficiency on fish growth.

No effect $(p>0.05)$ of vitamin supplementation was observed in this assay on weight gain, food conversion efficiency and feeding conversion. The influence of vitamins on fish performance has not been completely clarified. Similar results has been found in studies on vitamin $C$ and $E$ supplementation for channel catfish (Ictalurus punctatus), Labeo robita, piauçu (Leporinus obtusidens), and golden shiner (Noteminogus crysoleucas) (Chen et al., 2004; Ortuño et al., 2001; Mello et al., 1999). On the other hand, many studies have reported the positive effect of vitamin supplementation. Tilapia hybrids, Oreochromis niloticus $\times$ Oreochromis

Table 2 -Comparison between mean feed intake in Piaractus mesopotamicus fed diets supplemented with vitamin $\mathrm{C}$ and/or $\mathrm{E}$.

\begin{tabular}{lccc}
\hline \multicolumn{4}{c}{ Vitamin E (g per day) } \\
\hline Vitamin C & 0 & 250 & 500 \\
\hline--1 & $59.48 \mathrm{a}$ & $54.75 \mathrm{ab}$ & $54.44 \mathrm{~b}$ \\
0 & 54.76 & 56.99 & 55.90 \\
250 & 55.47 & 55.86 & 54.65 \\
\hline 500 &
\end{tabular}

Note: Identical letters in rows or columns: no difference $(p>$ 0.05). Lower case letters compare rows and upper case letters compare columns. 
aureus fed diet supplemented with an adequate level of vitamin $C$ but vitamin $\mathrm{E}$ free had smaller weight gain and feeding conversion than groups fed optimum levels of both vitamins. Shiau and Hsu (2002) suggested that vitamin $C$ supplementation at high levels (three times higher than the adequate level) can make up for the lack of vita$\mathrm{min} \mathrm{E}$ in the diet. Supplementation with zero or $160 \mathrm{mg}$ $\mathrm{kg}^{-1}$ vitamin $\mathrm{E}$ in feed associated with $250 \mathrm{mg} \mathrm{kg}^{-1}$ vitamin C over a 32 -week period increased the growth rate of Perca flavescens. So, in the long run, supplementation with vitamins $\mathrm{C}$ and $\mathrm{E}$ may improve fish performance (Lee and Dabrowski, 2004).

Regardless of the vitamin level in the diet, feed intake and food conversion efficiency increased from the first to the second month $(p \leq 0.05)$, while the condition factor was reduced. Erythrocyte, hematocrit, total protein, globulin, hemoglobin, MCHC, and thrombocyte counts increased from the first to the second month $(p \leq 0.01)$, while there were reductions in $\mathrm{MCV}$ and $\mathrm{MCH}$ values $(p \leq 0.01)$. Vitamin $\mathrm{E}$ affected the number of erythroblasts, so that the higher the level of this vitamin in the diet, the smaller the number of these cells (Figure 1). Erythropoiesis in fish occurs in the spleen and kidneys. Young erythrocyte forms are called erythroblasts, characterized by larger cell and nucleus sizes than mature erythrocytes (Tavares-Dias and Moraes, 2004). Vitamin $\mathrm{E}$ is a powerful antioxidant which extends erythrocyte life and is essential for cell respiration (Hung et al., 1981). Vitamin E deficiency induces erythrocyte fragility, causing their degeneration in many species such as Channel catfish (Wilson et al., 1984; Wise et al., 1993), Atlantic salmon (Hamre et al., 1997), rainbow trout (Furones et al., 1992), and pacu (Belo et al., 2005). Although erythrocyte fragility was not measured, fish fed a vitamin E-deficient diet showed lysed erythrocytes in blood smears. Therefore, to maintain an adequate erythrocyte level, it is suggested that fish should increase the production of erythroblasts to balance their loss in the blood.

Vitamin supplementation did not change hematocrit and hemoglobin values; however, these parameters were increased

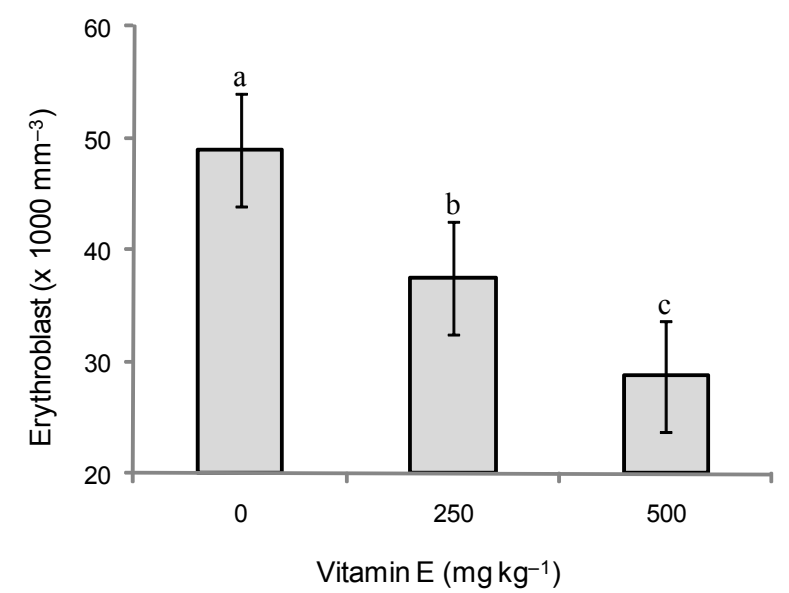

Figure 1 - Comparison between mean erythroblast counts in the blood of Piaractus mesopotamicus fed increasing levels of vitamin E during 60 days. Identical letters no difference $(p>0.05)$. from the first to the second month, as observed by Chen et al. (2003 and 2004) in golden shiner. Tavares-Dias et al. $(2000 \mathrm{a}, \mathrm{b})$ observed a positive correlation $(p \leq 0.01)$ between those blood parameters. Significant interaction was observed between vitamins $\mathrm{C}$ and $\mathrm{E}$ on the number of special granulocytes. The highest value found for this cell type was observed in the group which received the diet without vitamin C supplementation $\left(0 \mathrm{mg} \mathrm{kg}^{-1}\right)$ and $250 \mathrm{mg} \mathrm{kg}^{-1}$ vitamin $\mathrm{E}$ (Table 3). There was also interference of vitamin E supplementation on the number of special granulocytes (Table 4). The highest value found for this cell type was observed in the group which received the diet supplemented with 250 $\mathrm{mg} \mathrm{kg}^{-1}$ vitamin $\mathrm{E}$ for 60 days.

Table 3 - Comparison between mean numbers of special granulocytes $\left(\times 1,000 \mathrm{~mm}^{-3}\right)$ of Piaractus mesopotamicus fed diets supplemented with vitamin $\mathrm{C}$ and/or $\mathrm{E}$.

\begin{tabular}{llll}
\hline \multicolumn{4}{c}{ Vitamin E } \\
\hline Vitamin C & 0 & 250 & 500 \\
\hline---1 & $0.23 \mathrm{~b}$ & $2.36 \mathrm{Aa}$ & $0.47 \mathrm{~b}$ \\
0 & 0.45 & $0.39 \mathrm{~B}$ & 0.21 \\
250 & 0.54 & $0.61 \mathrm{~B}$ & 0.68 \\
\hline 500 &
\end{tabular}

Note: Identical letters in rows or columns: no difference $(p>$ $0.05)$. Lower case letters compare rows and upper case letters compare columns.

Table 4 - Comparison between mean numbers of thrombocytes, monocytes, and special granulocytes (SG) of Piaractus mesopotamicus fed diets supplemented with vitamins $\mathrm{C}$ and $\mathrm{E}$ as a function of feeding time.

\begin{tabular}{|c|c|c|}
\hline & \multicolumn{2}{|c|}{ Period } \\
\hline & 30 days & 60 days \\
\hline Vitamin C & \multicolumn{2}{|c|}{ thrombocytes } \\
\hline $\mathrm{mg} \mathrm{kg}{ }^{-1}$ & \multicolumn{2}{|c|}{----- $\times 1,000 \mathrm{~mm}^{-3}$} \\
\hline 0 & 47.18 & $62.21 \mathrm{C}$ \\
\hline 250 & $46.22 \mathrm{~b}$ & $74.53 \mathrm{Ba}$ \\
\hline 500 & $41.93 \mathrm{~b}$ & $90.40 \mathrm{Aa}$ \\
\hline Vitamin C & \multicolumn{2}{|l|}{ monocytes } \\
\hline $\mathrm{mg} \mathrm{kg}{ }^{-1}$ & \multicolumn{2}{|c|}{--------- $\times 1,000 \mathrm{~mm}^{-3}$} \\
\hline 0 & $1.30 \mathrm{AB}$ & $1.33 \mathrm{~B}$ \\
\hline 250 & $1.71 \mathrm{~A}$ & $1.32 \mathrm{~B}$ \\
\hline 500 & $1.05 \mathrm{Bb}$ & $2.40 \mathrm{Aa}$ \\
\hline Vitamin E & \multicolumn{2}{|c|}{ special granulocytes } \\
\hline $\mathrm{mg} \mathrm{kg}{ }^{-1}$ & \multicolumn{2}{|c|}{---------- $\times 1,000 \mathrm{~mm}^{-3}$--------- } \\
\hline 0 & 0.42 & $0.39 \mathrm{~B}$ \\
\hline 250 & $0.50 \mathrm{~b}$ & $1.74 \mathrm{Aa}$ \\
\hline 500 & 0.38 & $0.52 \mathrm{~B}$ \\
\hline
\end{tabular}

Note: Identical letters in rows or columns: no difference $(p>$ 0.05). Lower case letters compare rows and upper case letters compare columns. 
At 60 days of feeding, the number of thrombocyte cells increased to the level of vitamin $\mathrm{C}$ in the diet. In fish fed the two higher vitamin levels in the diet $(250$ and $500 \mathrm{mg}$ $\mathrm{kg}^{-1}$ ), the number of thrombocytes increased from the first to the second month (Table 4). Effect of this vitamin on the improvement of the number of thrombocytes in golden shiner was already reported (Chen et al., 2004). Bozzo et al. (2007) and Tavares-Dias et al. (2007) suggested that thrombocytes, as well as leukocytes, also have hemostatic functions and act as defense cells in fish. Supplementation with vitamin $\mathrm{C}$ increased the number of those cells in pacu; after the challenge by Aeromonas bydrophila, fish which received higher vitamin $\mathrm{C}$ levels showed a reduction on circulating thrombocytes, suggesting a migration of these cells to inflammation sites (Garcia et al., 2007).

The number of monocytes increased from the first to the second month of feeding only in the group which received the highest level of vitamin $\mathrm{C}$ in the diet $(500 \mathrm{mg}$ $\mathrm{kg}^{-1}$ ) (Table 4). In studies with the same species, feed supplementation with $500 \mathrm{mg} \mathrm{kg}^{-1}$ feed of vitamin $\mathrm{C}$ increased macrophages accumulation, as well as the formation of macrophage polykaryons on glass coverslips implanted into the subcutaneous tissue of $P$. mesopotamicus (Petric et al., 2003).

P. mesopotamicus which received diet deficient in vitamins $C$ and $E$ increased the feed intake, but no improvement on growth performance index could be seen. Vitamin $\mathrm{E}$ was essential for erythrocyte protection, because fish which received $500 \mathrm{mg}$ of this vitamin presented a reduction in the erythroblast number. Supplementation with $500 \mathrm{mg}$ of vitamin $\mathrm{C}$ and $250 \mathrm{mg}$ of vitamin $\mathrm{E}$ for 60 days increased the production of important cells of non specific defense mechanisms: monocytes, thrombocytes and special granulocytic cells in P. mesopotamicus and can be used as an important strategic management for pacu of fish farms.

\section{Acknowledgements}

To Prof. Dr. Euclides Braga Malheiros, "Departamento de Ciências Exatas, FCAV - UNESP" and "Laboratório de Análises Clínicas" at the same institution for technical and scientific cooperation. This research was financed by FAPESP.

\section{References}

Abimorad, E.G.; Carneiro, D.J. 2007. Digestibility and performance of pacu (Piaractus mesopotamicus) juveniles fed diet containing different protein, lipid and carbohydrate levels. Aquaculture Nutrition 13: 1-9.

Abimorad, E.G.; Favero, G.C.; Castellani, D.; Garcia, F.; Carneiro, D.J. 2009. Dietary supplementation of lysine and/or methionine on performance, nitrogen retention and excretion in pacu Piaractus mesopotamicus reared in cages. Aquaculture 295: 266-270.

Bai, S.C.; Lee, K. 1998. Different levels of dietary DL-alpha-tocopherol acetate affect the vitamin E status of juvenile Korean rockfish, Sebastes schlegeli. Aquaculture 161: 405-414.

Belo, M.A.A.; Schalch, S.H.C.; Moraes, F.R.; Soares, V.E.; Otoboni, A.M.M.B.; Moraes, J.E.R. 2005. Effect of dietary supplementation with vitamin $\mathrm{E}$ and stocking density on macrophage recruitment and giant cell formation in the teleost fish (Piaractus mesopotamicus). Journal of Comparative Pathology 133: 146-154.
Bozzo, F.R.; Moraes, J.R.E.; Moraes, F.R.; Pereira, G.T.; Tavares-Dias, M.; Onaka, E.M. 2007. Kinetics of cellular component in inflammatory response induced by different stimuli in the swim bladder of pacu, Piaractus mesopotamicus Holmberg 1887 (Characidae). Journal of World Aquaculture Society 38: 302-308.

Chen, R.G.; Lochmann, R.T.; Goodwin, A.; Praveen, K.; Dabrowski, K.; Lee, K.J. 2003. Alternative complement activity and resistance to heat stress in golden shiners Notemigonus crysoleucas are increased by dietary vitamin $\mathrm{C}$ levels in excess of requirements for prevention of deficiency signs. Journal of Nutrition 133: 2281-2286.

Chen, R.; Lochmann, R.; Goodwin, A.; Praveen, K.; Dabrowski, K.; Lee, K.J. 2004. Effects of dietary vitamins $\mathrm{C}$ and $\mathrm{E}$ on alternative complement activity, hematology, tissue composition, vitamin concentrations and response to heat stress in juvenile golden shiner (Notemigonus crysoleucas). Aquaculture 242: 553-569.

Chien, L.T.; Hwang, D.F.; Jeng, S.S. 1999. Effect of thermal stress on dietary requirement of vitamin $\mathrm{C}$ in Thornfish Terapon jarbua. Fish Science 65: 731-736.

Fujimoto, R.Y.; Carneiro, D.J. 2001. Addition of ascorbil polyphosphate as source of vitamin $\mathrm{C}$ in diets of the pintado Psendoplatystoma coruscans fingerlings (Agassiz, 1829). Acta Scientiarum 23: 855861. (in Portuguese with abstract in English).

Furones, M.D.; Alderman, D.J.; Bucke, D.; Fletcher, T.C.; Knox, D.; White, A. 1992. Dietary vitamin $\mathrm{E}$ and the response of rainbow trout, Oncorbynchus mykiss (Walbaum), to infection with Yersinia ruckeri. Journal of Fish Biology 41: 1037-1041.

Garcia, F.; Pilarski, F.; Onaka, E.M.; Moraes, F.R.; Martins, M.L. 2007. Hematology of Piaractus mesopotamicus fed diets supplemented with vitamins $\mathrm{C}$ and $\mathrm{E}$, challenged by Aeromonas hydrophila. Aquaculture 271: 39-46.

Goldenfarb, P.B.; Bowyer, F.P.; Hall, E.; Brosious, E. 1971. Reproducibility in the hematology laboratory: the microhematocrit determination. American Journal of Clinical Pathology 56: 35-39.

Halver, J.E. 1953. Fish diseases and nutrition. Transactions of the American Fishery Society 83: 254-261.

Hamre, K.; Waagbo, R.; Berge, R.K.; Lie, O. 1997. Vitamins C and E interact in juvenile Atlantic Salmon (Salmo salar, L.). Free Radical Biology Medicine 22: 137-149.

Hung, S.S.O.; Cho, C.Y.; Slinger, S.J. 1981. Effect of oxidized oil, dl-atocopherol acetate and ethoxyquin supplementation on the vitamin E nutrition of rainbow trout (Salmo gairdneri) fed practical diets. Journal of Nutrition 11: 648-657.

Jomori, R.; Carneiro, D.J.; Malheiros, E.B; Portella, M.C. 2003. Growth and survival of pacu Piaractus mesopotamicus (Holmberg, 1887) juveniles reared in ponds or at different initial larviculture periods indoors. Aquaculture 221: 277-287.

Lee, K.J.; Dabrowski, K. 2004. Long-Term effects in interactions of dietary vitamins $\mathrm{C}$ and $\mathrm{E}$ on growth and reproduction of yellow perch, Perca flavescens. Aquaculture 230: 377-389.

Martins, M.L.; Onaka, E.M.; Moraes, F.R.; Bozzo, F.R.; Mello, A.; Paiva, F.C.; Gonçalves, A. 2002. Recent studies on parasitic infections of freshwater cultivated fish in the State of São Paulo, Brazil. Acta Scientiarum 24: 981-985.

Mello, R.F.; Moura, M.A.M.; Vieira, I.; Cyrino, J.E.P. 1999. Vitamin C supplementation of piauçu (Leporinus obtusidens) fingerling diets. Scientia Agricola 56: 1223-1231. (in Portuguese with abstract in English).

Mitoma, C.; Smith, T.E. 1960. Studies on the role of ascorbic acid in collagen synthesis. Journal of Biology Chemistry 235: 426-428.

Navarre, O.; Halver, J.E. 1989. Disease resistance and humoral antibody production in rainbow trout fed high levels of vitamin C. Aquaculture 79: 207-221.

Ortuño, J.; Cuesta, A.; Esteban, M.A.; Meseguer, J. 2001. Effect of oral administration of high vitamin $\mathrm{C}$ and $\mathrm{E}$ dosages on the gilthead seabream (Sparus aurata L.) innate immune system. Veterinary Immunology Immunopathology 79: 167-180.

Petric, M.C.; Martins, M.L.; Onaka, E.M.; Moraes, J.R.E.; Moraes, F.R.; Malheiros, E.B. 2003. Dietary vitamin C supplementation potentiates the formation of giant cells in pacu Piaractus mesopotamicus Holmberg, 1887 (Osteichthyes: Characidae). Boletim do Instituto de Pesca 29: 69-76. (in Portuguese with abstract in English). 
Sarma, K.; Pal, A.K.; Sahu, N.P.; Ayappan, S.; Baruah, K. 2009. Dietary high protein and vitamin $\mathrm{C}$ mitigates endosulfan toxicity in the spotted murrel, Channa punctatus (Bloch, 1793). Science of the Total Environment 407: 3668-3673.

Sau, S.K.; Paul, B.N.; Mohanta, K.N.; Mohanty, S.N. 2004. Dietary vitamin E requirement, fish performance and carcass composition of rohu (Labeo rohita) fry. Aquaculture 240: 359-368.

Shiau, S.Y.; Hsu, C.Y. 2002. Vitamin E sparing effect by dietary vitamin $\mathrm{C}$ in juvenile hybrid tilapia, Oreochromis niloticus $\mathrm{x} O$. aureus. Aquaculture 210: 335-342.

Steel, R.G.D.; Torrie, J.H. 1960. Analysis of variance III. Factorial experiments. In: Steel, R.G.D.; Torrie, J.H., eds. Principles and procedures of statistics McGraw-Hill, New York, USA.

Tavares-Dias, M.; Moraes, F.R. Hematology of Teleosts Fish. 2004. Villimpress, Ribeirão Preto, SP, Brazil. (in Portuguese).

Tavares-Dias, M.; Schalch, S.H.C.; Martins, M.L.; Moraes, F. 2000a. Haematological evaluation of Tilapia rendalli Boulenger, 1896 (Osteichthyes: Cichlidae) captured in a fee fishing farm in Franca, São Paulo State, Brazil. Ars Veterinária 16: 76-82. (in Portuguese with abstract in English).

Tavares-Dias, M.; Schalch, S.H.C.; Martins, M.L.; Onaka, E.M.; Moraes, F.R. 2000b. Hematological characteristics of Brazilian Teleosts. III. Parameters of the hybrid tambacu (Piaractus mesopotamicus $\mathrm{x}$ Colossoma macropomum Cuvier) (Osteichthyes, Characidae). Revista Brasileira de Zoologia 17: 899-906.
Tavares-Dias, M.; Ono, E.A.; Pilarski, F.; Moraes, F.R. 2007. Can thrombocytes participate in the removal of cellular debris in the circulating blood of teleost fish? An cytochemical study and ultrastructural analysis. Journal of Applied Ichthyology 23: 709712.

Tocher, D.R.; Mourente, G.; Van Der Eecken, A.; Evjemo, J.O.; Días, E.; Bell, J.G.; Geurden, I.; Lavens, P.; Olsen, Y. 2002. Effects of dietary vitamin $\mathrm{E}$ on antioxidant defense mechanisms of juvenile turbot (Scophthalmus maximus L.), halibut (Hippoglossus hippoglossus L.) and sea bream (Sparus aurata L.). Aquaculture Nutrition 8: 195207.

Wilson, R.P.; Bowser, P.R.; Poe, W.E. 1984. Dietary vitamin E requirement of fingerling channel catfish. Journal of Nutrition 114: 2053-2058

Wintrobe, M.M. 1934. Variations on the size and hemoglobin content of erythrocytes in the blood various vertebrates. Folia Haematologica 51: 32-49.

Wise, D.J.; Tomasso, J.R.; Gatlin, D.M.; Bai, S.C.; Blazer, V.S. 1993. Effects of dietary selenium and vitamin $\mathrm{E}$ on red blood cell peroxidation, glutathione peroxidase activity, and macrophage superoxide anion production in channel catfish. Journal of Aquatic Animal Health 5: 177-182.

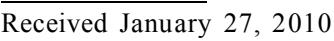

Accepted January 05, 2011 